\title{
On the emergence, current state, and future perspectives of Socially Responsible Investment (SRI)
}

\author{
Julia M. Puaschunder ${ }^{1} *$ \\ The New School, Department of Economics, Schwartz Center for Economic Policy Analysis, \\ Julia.Puaschunder@newschool.edu
}

\begin{abstract}
In recent decades Socially Responsible Investment (SRI) emerged into an en vogue investment philosophy. Originating from religious and moral considerations, SRI evolved in the wake of socio-political deficiencies and corporate social conduct. In the global rise of financial social conscientiousness, differing national legislations and regulatory traditions have led to various SRI practices, which are harmonized by the United Nations (UN). Building on the historic advancement of Financial Social Responsibility in the wake of socio-ethical deficiencies, this paper highlights the future potential of SRI in the aftermath of the 2008/09 World Financial Crisis as a means to avert economic market downfalls. During the current financial market reform, additional micro- and macro-research on financial social conduct could foster the idea of Financial Social Responsibility and aid a successful implementation of SRI.
\end{abstract}

Keywords: Economic crisis, Financial Social Responsibility, Socially Responsible Investment (SRI), 2008/09 World Financial Crisis.

\footnotetext{
${ }^{1}$ * Financial support of the Austrian Academy of Sciences, Austrian American Education Commission - Fulbright Commission, Eugene Lang Liberal Arts College of The New School, Fritz Thyssen Foundation, The Maxwell School of Citizenship and Public Affairs at Syracuse University, the Max Kade Foundation New York, New School for Social Research, Tishman Environment and Design Center, and the University of Vienna is gratefully acknowledged. The author declares no conflict of interest. The author thanks Professor Rainer Maderthaner and Professor Uwe Schubert for helpful comments on the presented ideas and/or earlier versions of the paper. All omissions, errors and misunderstandings in the following article are solely the author's.
} 


\section{Introduction}

As part of human nature, social responsibility guides corporate activities and financial considerations. The societal demand for imbuing social responsibility in economic markets has risen steadily in recent decades due to globalization and socio-political trends. In the current aftermath of the 2008/09 World Financial Crisis, the call for social responsibility in financial markets climaxed. The announcement of the recapitalization of the banking system in October 2008 created a need for reconsideration of social responsibility in a newly defined finance world. Heralding the "Age of Responsibility," the crisis led US president Barack Obama to call for a new spirit of responsibility that serves the greater goals of society (Washington Post, January 21, 2009). World Bank President Robert Zoellick describes the "new era of responsibility" featuring responsible corporate conduct and socially conscientious investments as means of societal progress (Financial Times, January 25, 2009).

The crisis' outbreak let mainstream economic theories' assumptions of unregulated markets being largely efficient appear in a new light. Classic finance theories' estimation of the collective outcomes of aggregated economic market actors' cognition blatantly underlined the importance of widening the interdisciplinary lens in the investigation of financial decision-making. Given the impetus of the 2008/09 World Financial Crisis and the renewed attention to social responsibility in economic markets, the interest in understanding ethicality in the finance world and advancing the idea of Financial Social Responsibility reached unprecedented momentum.

Financial social responsibility attributes the consideration of CSR in investment decisions (Puaschunder, 2010). Financial Social Responsibility bridges the financial world with society in Socially Responsible Investment (SRI). In this asset allocation style, socially conscientious investors select securities not only for their expected yield and volatility, but foremost for social, environmental, and institutional ethicality aspects (Beltratti, 2003; Mohr, Webb \& Harris, 2001; Williams, 2005). In the current climate of socio-economic crisis, the idea of Financial Social Responsibility appears as a means to reestablish trust in financial markets and potential panacea to avert future financial market downfalls. In this light, understanding financial social conscientiousness in financial markets appears more important than ever before to advance the idea of Financial Social Responsibility.

While the time is ripe to tackle the whole-rounded investigation of Financial Social Responsibility, we face SRI as a relatively novel and heterodox market option comprising multiple stakeholders around the globe. In the international arena, various SRI practices emerged concurrently. National rules and legal jurisdictions have shaped 
multiple corporate and financial social expressions as legal boundaries guide financial considerations and institutional frameworks predestine SRI conduct (Reinhardt, Vietor \& Stavins, 2008; Steurer, 2010). Regional settings and economic customs have contributed to the culture-dependence of SRI.

As a first step toward resolving societal losses imbued in the complexity of this novel phenomenon but also to innovatively explore new opportunities to ingrain social responsibility within globalized market economies, this paper will present the history of SRI and international practice of Financial Social Responsibility in order to draw conclusions about the future potential of SRI in the aftermath of the 2008/09 World Financial Crisis. The historic emergence of Financial Social Responsibility shows social conscientiousness to peak in the wake of socio-economic deficiencies, humanitarian downfalls, and legislative compulsion, which provides a convincing case for the appreciation of the current crisis' role to ingraining ethicality in economic markets. Studying the emergence of SRI in economic markets and taking a snapshot of where we stand with SRI during a time of financial turmoil will also inform circumstances under which social responsibility is likely to prosper. Reflecting financial social conscientiousness through a historic lens will in addition help in deriving natural Financial Social Responsibility triggers and SRI success factors in order to aid the ongoing adoption of SRI around the globe.

In the international arena, external influences have shaped the practice of Financial Social Responsibility. National legislations, policy frameworks, and cultural landscapes have brought out differing SRI forms as governmental forces and institutional incentives either curb or perpetuate specific financial social considerations. With no stringent legal international basis, in some parts of the world, SRI activities are mandated by national, federal, state, or local laws and regulations. In others, the judicial record leaves room for investors to allocate resources in a socially conscientious way. Until today our insights on external forces shaping SRI customs, however, remain rudimentary. SRI practices are still inconclusive in the global arena leading to disparate SRI notions throughout the world. Capturing the current state of SRI around the world will give a more conclusive picture of Financial Social Responsibility. Analyzing financial social considerations on a global scale through a prism of legal setting and institutional customs will help in finding mutually shared contents of financial social investment. Paying attention to international differences of SRI options will also serve as a first step to harmonize differing Financial Social Responsibility practices in the ongoing SRI adaptation around the globe. Enabling a more harmonious discourse on SRI will reduce the complexity of SRI and diminish socio-economic losses imbued in the ambiguity of this multi-stakeholder phenomenon. 
Studying the manifold SRI expressions resulting from the various interplays of governmental, corporate, and financial market forces will also allow drawing inferences about positive framework and boundary conditions of financial social conscientiousness. International SRI descriptions will thus offer insights on Financial Social Responsibility triggers and repeatable patterns as a basis for successful SRI policies within financial markets.

Advancing Financial Social Responsibility technically and aiding to mainstream financial social endeavors but also fostering the SRI acceptance throughout the investment community promises to strengthen SRI's global governance contribution (Bruyn, 1987). Following this goal, international organizations have started to align differing SRI practices. The United Nations (UN) leads the institutional harmonization of Financial Social Responsibility in capturing diverse SRI actions. In the pursuit of finding an overarching SRI framework, the UN unifies disparate Financial Social Responsibility approaches and promotes consensus finding on SRI as a multi-stakeholder means for attributing societal global governance goals.

Only by understanding our past can we excel in the future. Outlining the historic root of Financial Social Responsibility and the current state-of-the-art international SRI practice will help drawing inferences about the future potential of Financial Social Responsibility. As we may conclude, recent developments in the aftermath of the 2008/09 World Financial Crisis promise to hold favorable conditions for the advancement of SRI. In the aftermath of economic downturns, more than ever SRI opens a prospective avenue to ingrain financial social considerations in globalizing economies. SRI appears as an already existing means to re-establish trust in financial markets and aid financial market stability. In this vibrant field, however, more research on Financial Social Responsibility is needed to predict SRI as a panacea to avert future economic crises and successfully contribute to future financial social global governance.

\section{Socially Responsible Investment (SRI)}

Socially Responsible Investment (SRI) is an investment philosophy that combines profit maximization with social endeavors (Livesey, 2002; Matten \& Crane, 2005; Wolff, 2002). By integrating social, environmental and financial aspects in investments, socially conscientious investors pursue economic and social value maximization alike (Renneboog, Horst \& Zhang, 2007; Schueth, 2003). Financial goals can be coupled with catalyzing socio-political change in various forms (Mohr et al., 2001).

Socially responsible screenings are 'double bottom line analyses' of corporate economic performance and social responsibility, in which socially conscientious investors incorporate Corporate Social 
Responsibility (CSR) in financial decision-making and allocate financial resources based on the societal impacts of the funded entities. Screenings evaluate options on economic fundamentals as well as qualitative intra- (e.g., corporate policies and practices, employee relations) and extra-organizational (e.g., externalities on current and future constituents) corporate social conduct (Schueth, 2003). Screenings watch corporate track records of societal impacts, environmental performance, human rights attribution, fair workplace policies, and health and safety standards. Positive screenings select corporations with sound social and environmental records that pay attention to human rights and labor standards, equal opportunities, environmental protection, consumer safety, community concerns, and stakeholder relations. Negative screenings exclude corporations that contribute to socially irresponsible activities such as addictive products and services (e.g., liquor, tobacco, gambling), defense (e.g., weapons, firearms, landmines), environmentally hazardous production (e.g., pollution, nuclear power), and humanitarian deficiencies (e.g., discrimination, human rights violations). Specialty screenings target extraordinary executive compensation, abortion, and animal testing (Dupré, Girerd-Potin \& Kassoua, 2008). Post-hoc negative screenings lead to the removal of investment capital from markets to attribute global governance goals (Broadhurst, Watson \& Marshall, 2003; Harvey, 2008; McWilliams \& Siegel, 2000). In political divestiture, socially responsible investors use their market power to pressure politically incorrect governments counterparting from international peace laws steering war, social conflict, terrorism, and human rights violations (Schueth, 2003; Starr, 2008). Prominent public divestiture cases are the capital flight from South Africa during Apartheid, investor responses to the human rights violations in Burma and the capital drain during the humanitarian crises in Sudan's Darfur region.

Screenings are often complemented with shareholder advocacy and activism - the active engagement of shareholders in corporate policy and managerial decision-making (Little, 2008; Schueth, 2003; Sparkes \& Cowton, 2004). Resolutions allow shareholders to request corporate board information and vote on corporate issues in shareholder meetings. The vast majority of shareholders exercise their voting rights by proxy, which grants third parties voting rights on matters before the corporation (Little, 2008). Current trends of mutual fund proxy disclosure regulations target the public availability of corporate records. Related active endowments establish procedures for integrating social responsibility in university endowments through proxy voting. Informal shareholder dialogues influence corporate policies and practices without formal resolutions and investment withdrawals. Shareholder activism also comprises pro-social political lobbying, consumer boycotts, and corporate confrontations drawing public attention to corporate social conduct (Sparkes \& Cowton, 2004). 
Community investing started in the 1970s with direct investments and investor set-asides for underserved low-income groups (Schueth, 2003). Community development banks provide at-risk communities access to financial services - including credits, equity, and banking products - to support housing, education, childcare, and healthcare. Community development venture capital funds startups in underdeveloped regions (Schueth, 2003). Related social venture capital supports social entrepreneurs to vitalize communities and foster positive societal change. Supplementary financial empowerment targets financial education, mentoring, and assistance.

Today's Financial Social Responsibility expressions are manifold, and forecasts predict a growth in diversity (Little, 2008; Social Investment Forum Report, 2006). SRI already embraces a variety of stakeholders comprising economic (e.g., institutional and private investors), organizational (e.g., labor union members, banking executives, fiduciaries), and societal constituents (e.g., representatives of international organizations and non-governmental organizations, governmental officials, public policy specialists, nonprofits, media spokesperson, academics). Consequently, SRI touches on diverse interests. The multitude of ideas and parties involved leads to a disparity of Financial Social Responsibility endeavors that may cause multi-stakeholder deficiencies. To reduce the complexity of the phenomenon and overcome socio-economic losses implied by various Financial Social Responsibility approaches, the various SRI phenomena must be scrutinized. As a first step in this direction, we may start by shedding light on the history of human ethical considerations entering financial markets.

\section{Historical emergence}

Social and ethical considerations in financial markets have a long tradition stemming from religious roots. Already in medieval times, Christianity imposed financial restrictions based on the Old Testament. The Catholic Church prohibited usury as early as 1139. Judaist writings praised ethical monetary conduct. Methodism urged to avoid 'sinful' trade and profit maximizing exploitation (Cuesta \& Valor, 2007). Since the $17^{\text {th }}$ century, the Quaker Society of Friends refrained from military and slave trade. The UK Methodist Church advocated for ethical corporate conduct. The Christian Pioneer Fund was first to officially exclude 'sin stocks.' Until today, Islamic banking has restricted adult entertainment and gambling (Renneboog et al., 2007).

The early beginnings of modern SRI are attributed to social responsibility concerns in the face of social, environmental, and political deficiencies and humanitarian crises (Williams, 2005). In the post-World War II era, first financial social considerations ideas sparked in the wake of legislative compulsion, information disclosure, 
and governmental policies encouraging trustees' social responsibility (Solomon, Solomon \& Norton, 2002; Sparkes \& Cowton, 2004). During the 1960s stakeholder pressure and anti-Vietnam War movements alerted institutional investors to sell napalm-producing Dow Chemical shares (Biller, 2007). Civil rights campaigns and social justice initiatives opposed college endowments funding warfare. Minority empowerment, consumer rights activism, and environmentalism sensitized for financial social conscientiousness (Renneboog et al., 2007; Sparkes, 2002). Since 1969 the Council on Economic Priorities rated corporate social and environmental performance. After a Yale conference introduced Financial Social Responsibility, many universities established committees to advise trustees on social investment. Subsequently Methodist clergy created the PAX World Fund aimed at divestiture from Vietnam War supporters (Broadhurst et al., 2003; Renneboog et al., 2007). The Dreyfus Third Century Fund opened the following year to avoid 'sin stocks' and improve social labor standards. By the mid-1970s, a significant number of governments had enacted shareholder rights to address corporate activities that caused 'social injury,' and many universities established committees to advise trustees on SRI and shareholder rights. The Investor Responsibility Research Center (IRRC) and the Interfaith Center on Corporate Responsibility (ICCR) were launched to promote shareholder advocacy and proxy resolutions around the same time (Social Investment Forum Report, 2006). In 1972 activists criticized Harvard University for owning shares in petroleum corporations. Political divestiture became firstly discussed in the case of the Angolan repressive government (Alperson, Tepper-Marlin, Schorsch \& Wil, 1991). In 1976 Reverend Leon Sullivan - a civil rights activist and director of General Motors - developed the Sullivan Principles to foster equal remuneration and workplace opportunities to empower minorities (Voorhes, 1999). During the 1980s, political divestiture was practiced by US universities, investors, churches, city governments, and state governments as a means to dismantle the South African Apartheid regime featuring racial segregation and economic discrimination against non-European groups (Schueth, 2003; Soros, 2008). Environmental catastrophes in Chernobyl, Bhopal, and the Exxon Valdez oil spill perpetuated shareholder activism. With the desire to set standards for corporate social engagement and environmentally conscientious conduct, social investors started positive screenings in the beginning of the 1990s. The Domini 400 Social Index institutionalized ratings of Standard \& Poor's 500 (S\&P) corporations. The micro-finance revolution and the co-operative banking system further galvanized the idea of SRI (Brenner, 2001).

Within recent decades Financial Social Responsibility boomed in the wake of globalization and political trends. An unprecedented interconnectivity of globalized financial markets strengthened the 
societal role of financial institutions. Political libertarianism implicitly shifted social responsibility onto the private sector. Deregulated liberalization attributed a rising share of global governance onto financial markets. Financial social considerations leveraged an implicit fiduciary responsibility (Solomon et al., 2002; Sparkes \& Cowton, 2004). As social global governance has increasingly entered financial markets since the turn of the millennium, a growing proportion of investment firms and governmental agencies around the world adopted a more socially conscientious investment philosophy (Knoll, 2008; McCann, Solomon \& Solomon, 2003; Sparkes, 2002). Information disclosure on corporate social conduct in combination with benchmarking of corporate social engagement and governmental encouragement of trustees' social conscientiousness propelled SRI. Institutional investors concurrently used their clout to influence corporate conduct and actively demanded corporate governance reforms to act on societal concerns. The advanced consideration of Financial Social Responsibility by major institutional investors matured SRI from a niche market option that was offered by specialist retailers to a more mainstream asset allocation style (Mathieu, 2000; Sparkes \& Cowton, 2004). SRI reached unprecedented diversity featuring a wide range of social engagement possibilities (Rosen, Sandler \& Shani, 1991). As SRI gained in prominence and broadened in size, scale, and scope, practitioners and academics started documenting state-of-the-art Financial Social Responsibility practices. Business professionals reported and analysts monitored social, ethical, and environmental corporate performance. Social and environmental stock exchange rating agencies and certifications measured SRI impacts.

Today business leaders tend to contribute to the creation of economic and societal progress in a globally responsible and sustainable way by means as never before experienced. Corporations that join the United Nations Principles of Responsible Investment (PRI) report concomitant tangible (profit gain, efficiency, product innovations, market segmentation) and intangible (reputation, employee morale) benefits. The United Nations Environment Programme Finance Initiative (UNEPFI), the Equator Principles, The Green Bond Principles, and the various corporate reporting lead initiatives such as Global Reporting Initiative (GRI) and Integrating Reporting (IR) are additional UN responsible investment activities. The key constituents are stock exchange and financial analyst communities as future SRI drivers to support the UNGC goals. In addition, NGOs are invited to advance financial market transparency and accountability (Puaschunder, 2016b).

In light of the rising climate change awareness and demand for an economically efficient transitioning into renewable energy, the UNled Earth League most recently incepted the Climate Risk and the 
Finance Sector working group in partnership with United Nations Environment Programme Finance Initiative (UNEP FI), the World Resources Institute (WRI), and the Global Challenges Foundation. The UNEP FI is a global partnership between UNEP and the financial sector. Over 200 institutions, including banks, insurers, and fund managers, work together with UNEP to capture the mutual impacts of environmental and social considerations on financial performance (Puaschunder, 2016b).

At the $3^{\text {rd }}$ Conference on Financing for Development in July 2015 in Addis Ababa, and at the global summit on the Sustainable Development Goals in New York City in September 2015, external financing for development was proven as key driver of developing economies. In the wake of the 2015 inception of the UN Sustainable Development Goals, a report was published by UNEP FI in cooperation with the PRI, UNEP Inquire, and the UNGC that aims at elucidating debates surrounding environmental, social, and governance issues in the light of fiduciary duty. The report is meant to foster investors' understanding and consideration of environmental, social and governance (ESG) issues in their investment decision-making. The research stresses the point that a failure to consider long-term investment value drivers including ESG issues in investment practices is a failure of fiduciary duty. The report also touches on the implementation of sustainable finance and impact investment in order to propose practical action for institutional investors, financial professionals, and policy-makers to embrace sustainable development (Puaschunder, 2016b).

One of the most novel trends is the acknowledgement of the role of political divestiture for sustainable development (Puaschunder, 2016b). With political divestiture having increasingly become an element of fiduciary duty, particularly for investors with long-term horizons that oversee international portfolios, this Financial Social Responsibility means has also come closer to serving sustainable development. Sustainable investment is needed in global economic growth and development, especially in light of financing the SDGs and developing countries being highly dependent on corporate contributions. There are massive worldwide financing needs for sustainable development, and FDI plays a crucial role in bridging the investment gap, especially in developing countries. Due to stability and diverse development impact compared with other sources of finance, FDI is the most important component of external development finance to fragile economies. Over the past decade, FDI stock tripled in least developed countries and small-island developing economies and quadrupled in landlocked developing countries. At the same time, inward FDI to the developing economics reached their highest level at USD 681 billion with a 2 percent rise in 2015 (Puaschunder, 2016b; World Investment Report, 2015). According to the World Investment 
Report 2015, investment community trends will still be geared toward investment liberalization, promotion, and facilitation in the future. Global FDI flows are expected to reach $\$ 1.4$ trillion in 2015, an 11 percent rise. Flows are expected to increase further to $\$ 1.5$ trillion and \$1.7 trillion in 2016 and 2017 (World Investment Report, 2015). With a concerted effort by the international investment development community, FDI in weak economics could quadruple by 2030. In the future, economic diversification should target fostering greater sustainability in these most vulnerable countries (Puaschunder, 2016b; World Investment Report, 2015). For the future the world's leading Stock Exchange Commissions seek to further support the PRI and consider innovative ways of how to partner with the UNGC. Sustainable development impact reporting can thereby highlight sustainable development criteria such as environmental and social standards. For instance, the United States' Overseas Private Investment Corporation (OPIC) uses about 30 development indicators to evaluate job creation and human capacity building, sustainability effects, as well as impacts on environmental and community benefits (World Investment Report, 2015). In addition, specific sustainable development outcomes could be screened for industrial development and regional economic cooperation. Future monitoring could comprise of an ombudsperson and facilitator to help ensure a vital sustainability climate.

This qualitative and quantitative emergence of financial social market options and the rising attention to SRI for global governance, however, also caused a disparity of SRI practices. In the quickly changing, unregulated market systems of today, we face a lack of indepth analysis of Financial Social Responsibility phenomena. Lately weakened market economies caused by an inadequate understanding of financial social conscientiousness underline the urgency and importance of a whole-rounded investigation of SRI. While diversity of SRI practices is welcome to reach out to various constituents and clients, a classification of the differing Financial Social Responsibility practices throughout the world may serve as a prerequisite for a pinpointed SRI support on a grand scale. As a first step in this direction, shedding light on international differences of SRI may hold the potential to draw conclusions about positive framework and boundary conditions for a successful implementation of SRI.

Analytic investigations will also help to shed light on the efficiency and unknown potentials as well as possible downturns of SRI. In a cost and benefit analysis, SRI implies short-term expenditures, but grants long-term sustainable investment streams.

In the short run, screened funds have a higher expense ratio in comparison to unscreened ones - that is, social responsibility imposes an instantaneous 'ethical penalty' of decreased immediate shareholder revenue (Mohr \& Webb, 2005; Tippet, 2001). In addition, for investors 
the search for information and learning about CSR is associated with cognitive costs. Screening requires an extra analytical step in decisionmaking, whereby positive screens are believed to be more cognitively intensive than negative ones (Little, 2008). Screening out financial options lowers the degrees of freedom of a full-choice market spectrum and risk diversification possibilities (Biller, 2007; Mohr \& Webb, 2005; Williams, 2005).

In the long run, SRI options offer higher stability, lower turnover and failure rates compared to general assets (Dhrymes, 1998; Geczy, Stambaugh \& Levin, 2003; Guenster, Derwall, Bauer \& Koedijk, 2005; Schroeder, 2003; Stone, Guerard, Gületkin \& Adams, 2001). Based on more elaborate decision-making processes, once investors have made their socially responsible decision, they are more likely to stay with their choice (Little, 2008). As a matter of fact, SRI options are less volatile and more robust during cyclical changes (Bollen \& Cohen, 2004). SRI measurement deficiencies stem from intangible and time-inconsistent pay-offs as well as measurement errors. SRI studies are methodologically limited for small sample sizes due to the relative novelty of Financial Social Responsibility, inconsistencies in the short time frames under scrutiny, and differing modelling techniques used to estimate investment returns (Jones, van der Laan, Frost \& Loftus, 2008; McWilliams \& Siegel, 1996; Mohr et al., 2001; Ngassam, 1992; Teoh, Welch \& Wazzan, 1999). Most SRI studies do not take externalities on the wider constituency group into consideration, which lowers the external validity of the results and calls for a more whole-rounded examination of SRI with a global perspective (McWilliams et al., 1999).

\section{International differences}

SRI bridges the finance world with society (Schueth, 2003). In the international arena, various SRI practices emerged concurrently as national rules and legal jurisdictions shape corporate and financial social conduct (Steurer, 2010). Legal boundaries guide financial considerations and institutional frameworks predestine Financial Social Responsibility practices (Reinhardt et al., 2008). Regional settings and economic customs add to the culture-dependence of SRI.

Financial Social Responsibility booms in the Western World and has primarily been adopted in Central Europe and Anglo-Saxon markets. Whilst Anglo-Saxon countries (such as the US and UK) are prominent for private investments; European financial systems are renowned for governmental and institutional banking. Common law Anglo-Saxon countries (e.g., US, Canada, Australia, UK) are more liberal in institutionalizing SRI (Matten \& Moon, 2004). Anglo-Saxon fiduciary responsibility focuses stronger on return on investments, while Western European Roman Law-dominated countries legally 
grant fiduciaries more leeway in considering the overall societal impact of the asset-issuing entities. Civil law countries (e.g., central European countries) tend to place greater emphasis on stakeholder participation in corporate governance (Reinhardt et al., 2008).

\section{North America}

Despite drawbacks during the 2008/09 financial crisis, the US is home to half of the world's capital and publicly-traded corporations. Hosting 7,000 self-made millionaires and 170 billionaires, the US political and legal systems disproportionately reward capital allocation talent. Featuring a liberal market economy, the US benefits from a comprehensive set of market transparency rules, a vigorous, free media, and highly educated market actors. The US Constitutional Law endows with substantive rights of freedom of speech, assembly or association, press, religious exercise, as well as property securitization. The US is renowned for explicit CSR expression combined with a competitive market and relatively low governmental social welfare (Roberts, 2006).

Having grown out of niche market options for value-led investors, SRI prospered in the US due to disclosure of corporate social externalities and shareholder activism in the wake of socio-political concerns. The 1981-enacted American Social Investment Forum - as a professional body for individual and institutional SRI constituents introduced SRI to the American market (Broadhurst et al., 2003). The 1986 US Comprehensive Anti-Apartheid Act legally backed billions of divested dollars from South Africa to weaken a discriminatory government. Since 2004 various corporate scandals led to legislations addressing disclosure of proxy votes, which leveraged shareholder resolutions to become the mainstream track record for socially responsible corporate conduct (Little, 2008). In numeric terms, 348 resolutions on social and environmental issues were proposed in the US, of which more than 50 percent reached a proxy vote in 2005 (Social Investment Forum, 2006). The same year US \$ 2.5 trillion assets were attributed as socially responsible funds, which accounted for 20.7 percent of all US investments (Williams, 2005). Today the US features - in a landscape of highly dispersed share ownership - by far the broadest variety of SRI options and socially responsible performance measurement indices.

In Canada, legal obligations require corporate directors and officers to act in the best interest of the entity without ignoring stakeholders (Borok, 2003). SRI was officially introduced in Canada by the Ethical Growth Fund in 1986 (Williams, 2005). Based on the US model, the 2001 Canadian Institute of Chartered Accountants established disclosure guidelines backed by mandatory obligations (Sparkes \& Cowton, 2004). Since 2006 the Canadian Securities 
Administrators mandated mutual funds to publicly disclose their proxy voting policies and records. SRI is organized by the Social Investment Organization (SIO) renowned for surveys and conferences (Williams, 2005). Community investing recently boomed in Canada (Social Investment Forum Report, 2006).

\section{Europe}

Europe has a long history of incorporating corporate social conduct in institutional investments (Reinhardt et al., 2008; Sutton, 2004). As European legislations emphasize stakeholder participation in corporate governance, European corporate boards often include employee representatives. Civil law countries tend to codify profitsacrificing corporate behavior as cultural traditions value corporate social conscientiousness. While the more liberal UK permits corporate managers to engage in socially beneficial activities as long as this is in the shareholders' greater interests, social democracies - such as France and German-speaking countries - legally back stakeholder interests (Lynch-Fannon, 2007; Reinhardt et al., 2008; Roe, 2000). The German corporate law does not even explicitly oblige the management to maximize shareholder value (Corfield, 1998; Marinov \& Heiman, 1998). While SRI booms in Northern and Central Europe, the movement is slower to take off in Southern Europe. Community investing is prominent in Latin countries like Italy, France, and Spain. ${ }^{2}$

Quantitatively, the growing European SRI market (excluding the Nordic region) recently comprised around 400 green, social, and ethical funds worth $€ 1.138$ billion in 2008 , accounting for 18 percent of the market share. ${ }^{3}$ The UK leads the SRI movement with $€ 8.0$ billion in total assets, followed by Germany (with $€ 6.7$ billion), Austria ( $€ 5.3$ billion), France (€3.1 billion), Switzerland ( $€ 2.9$ billion), Italy (€2.7 billion), and Sweden ( $€ 2.5$ billion) in 2006.

In the UK - the European SRI leader - first UK Victorian concerns about employment conditions sparked corporate social conduct (Sparkes, 2002). Ethical finance was established by the Mercury Provident in 1974 and introduced to retail banking in 1992. In 1997 a group of university affiliates launched a campaign for ethical and environmental pension funds. Since 2000 Sustainable and Responsible Investment policies require all occupational pension funds to formally consult adopting social, ethical, and environmental policies (Sparkes \& Cowton, 2004; Williams, 2005). The UK government regulations reassured pension funds to declare the extent to which environmental, social, or ethical considerations are taken into consideration in the selection, retention, and realization of investments

\footnotetext{
${ }^{2}$ European Social Investment Forum report retrieved from the internet in January 2009 at http://www.eurosif.org/

${ }^{3}$ European Social Investment Forum report retrieved from the internet in January 2009 at http://www.eurosif.org/
} 
(Sparkes, 2002). Similar regulations have been passed in Germany and Sweden and are currently considered by the European Parliament (Steurer, 2010).

The Nordic European countries are renowned for a Scandinavian Law framework. Political divestiture was enacted by the Belgian government in 2007 by restricting Belgian investors to finance warfare (Steurer, 2010). Sweden's 2000 Public Pension Fund Act required all Swedish National Pension Funds to report investments' environmental and social externalities (Steurer, 2010). While the law gives leeway to what extent funds have to comply, it helped in granting access to information and raising awareness for SRI. In addition, Joint Ethical Council offers investment recommendations for stakeholders (Steurer, 2010). The Dutch Green Funds Scheme provides information on SRI tax exemptions (Steurer, 2010).

In Continental Europe, the French Pension Research Fund offers insurance plans in line with SRI principles. In German-speaking Roman Law countries, SRI was propelled in the wake of peace movements and the 1970s green wave promoting environmental protection. The Gemeinschafts- and Ökobank were first SRI traders. Major influences are attributed to Green Parties, the 1991 Renewable Energy Act, information campaigns, and tax exemptions (Williams, 2005).

\section{The Pacific Rim}

Australian corporate law requires corporate managers to make decisions in the best interest of the corporation, yet a statutory business judgment rule grants considerable discretion (Reinhardt et al., 1998). Australian direct share ownership led to higher levels of individual investors' SRI screenings.

The first Australian ethical investment movement began in the early 1980s leading to the Australian Ethical Investment Trust in 1989 (Cummings, 2000). The Ethical Investment Association (EIA) emerged throughout the 1990s to launch SRI benchmarking reports and a SRI symbol to approve socially responsible products (Williams, 2005). The Financial Service Reform Act 2002 introduced financial disclosure statements. In 2003 the Australian Securities and Investment Commission (ASIC) issued SRI disclosure guidelines (Williams, 2005). From 2001 to 2004, SRI rose by over 100 percent from AUS $\$ 10.5$ to $\$ 21.5$ billion - making SRI the fastest growing investment segment in Australia (Jones et al., 2008).

\section{Emerging markets}

SRI drives international development in emerging markets foremost through community investing, microfinance, and enterprise 
development for social entrepreneurs (Social Investment Forum Report, 2006). Newly emerging and rapidly growing SRI markets are Latin America (foremost Brazil) and South Africa. Asia is a potential future ripe market for SRI - reaching US \$2.7 billion in total SRI assets (Sparkes \& Cowton, 2004). Japan accounted for Asia's leading SRI market with more than 100 billion yen spread over ten SRI funds. The 2011 crisis followed by a financial investment drain from Japan, however, may slow or even halt this trend. Hong Kong as Asia's additional SRI expansion market may take over the lead in Asia. More than twelve screened funds are available in the Islamic banking territories of Malaysia, Taiwan, and Singapore.

In the developing world, SRI practices vary across countries as laws and regulations are often not well-enforced (Reinhardt et al., 2008). Missing Financial Social Responsibility standardization hampers the adoption of SRI. Oversea oversight is challenged by a lack of accountability of SRI practices and non-transferable customs. Standardized SRI policies could help regulatory enforcement and monitoring to overcome principal-agency discrepancies, conflicts of interest, and corruption. To diminish the likelihood of these downfalls but foremost to foster the idea of Financial Social Responsibility through a harmonious understanding of SRI on a grand scale, international organizations have set out to harmonize Financial Social Responsibility practices in the global arena.

\section{Institutional harmonization of SRI}

In the eye of globalized markets and international societal challenges (e.g., in the environmental domain such as climate change), international organizations currently harmonize differing SRI practices throughout the international arena. International organizations define SRI standards and guideline the Financial Social Responsibility implementation from a global governance perspective. A more harmonious picture of concerted Financial Social Responsibility is meant to foster financial markets' global governance impetus in the pursuit of societal goals.

Transnational entities play a pivotal role in institutionally supporting Financial Social Responsibility and streamlining disparate SRI practices throughout the world. The United Nations (UN) leads the international public administration of Financial Social Responsibility. In January 2004, the UN invited a group of leading financial institutions to form a joint financial sector initiative under the guidance of the United Nations Global Compact's (UNGC) Board to discuss financial investment banks and fiduciaries' social responsibility implementation. In associated research units, the initiative developed guidelines on how to integrate environmental, social, and corporate governance in asset management and securities brokerage services. 
Subsequently responding to rising SRI trends all over the world, the UNGC division and the UN Environment Programme Finance Initiative launched the 'Principles for Responsible Investment' in collaboration with the New York Stock Exchange (NYSE) in 2006. The PRI are supported by the UNGC Conference Board, the chief executive officers of global corporations, the International Finance Corporation of the World Bank Group, the Swiss Government, and Columbia University. The principles are designed to place Financial Social Responsibility into the core of investment decision-making of financial managers, asset owners, and institutional endowment holders. The PRI support socially responsible investors and harmonize financial social conscientiousness to create repeatable models for positive societal change within the investment community. Under the auspice of the UNGC and the UNEP Finance Initiative, the PRI invite institutional investors to consider SRI and mobilize chief executive officers of the world's largest pension funds to advance financial social considerations at the international level. At the one-year anniversary of the PRI, more than 170 institutions - representing approximately USD 8 trillion in assets - had committed to the PRI. ${ }^{4}$ Corporations joining the PRI have been reporting profits, efficiency, product innovation, and market segmentation advantages but also intangible reputational gains, improved employee morale, and consumer satisfaction.

In February 2008 the UN Conference on Trade and Development (UNCTAD) launched the 'Responsible Investment in Emerging Markets' initiative at the Geneva PRI office. This publicprivate partnership fosters transparency and disclosure for the integration of environmental, social, and corporate governance in emerging markets. The key constituents are stock exchange and financial analyst communities. NGOs are invited to advance accountability. Investment banks and fiduciaries are assisted to implement social responsibility as a risk management tool.

The 2008/09 World Financial Crisis has put a novel perspective on the promotion of Financial Social Responsibility. Above the advancement of global governance goals through the engagement of financial markets, the idea of SRI began to offer the prospect of market stability as the 2008/09 financial turmoil had proved Financial Social Responsibility as an essential well functioning of financial markets.

\section{SRI in the light of the 2008/09 World Financial Crisis}

Starting in the 1970 s, financial markets increasingly became interweaved with socio-politics. The diminishing power of nation states

\footnotetext{
${ }^{4}$ Who cares wins: Connecting financial markets to a changing world: Recommendations by the financial industry to better integrate environmental, social and governance issues in analysis, asset management and securities brokerage. The United Nations Global Compact Office. Retrieved from the internet at http://www.unglobalcompact.org/docs/news_events/8.1/WhoCaresWins.pdf
} 
in a globalizing world shifted social responsibility attribution onto the private sector (Ahmad, 2008; Puaschunder, 2010). Since the 1990s, capitalism has grown into the triumphant market system and upcoming financial market dominance was forecasted. Financial Social Responsibility increasingly leveraged a global governance means in the wake of financial markets' outreach into socio-political affairs. Rising levels of social venture capital for international development led to predictions about the increasing influence of financial markets in public affairs and social welfare provision. The 2008/09 World Financial Crisis, however, put new perspectives on financial markets' global hegemony and redefined the impetus of the investment world in global affairs.

The 2008/09 World Financial Crisis' impact on economic markets, international financial policy frameworks, and society is indubitable. Caused by the neglect of social responsibility of fallible market actors coupled with absent accountability in liberal markets, the world economy weakened beginning around August 2008. The crisis caused what Alan Greenspan called a 'once in a century credit tsunami' featuring governmental takeovers and corporate bailouts, a lock-up of credit markets and inter-bank lending, a 25 percent drop in financial market indices, bailed-out European countries, and a hampered US economy (Duchac, 2008).

After the steady rise of SRI in recent decades, stakeholder concerns for Financial Social Responsibility climaxed in the eye of the 2008 financial meltdown. Since the outbreak of the crisis, the societal call for social responsibility in corporate and financial markets has reached unprecedented momentum. The revelation of corporate social misconduct and financial fraud steered consumers and investors to increasingly pay attention to social responsibility within market systems (Roberts, 2010). Media coverage of corporate scandals, fiduciary breaches, and astronomic CEO remuneration fostered the need for financial social conscientiousness. Financial managers' exuberance fueled the demand for transparent and accountable corporate conduct. Stakeholder pressure addressed information disclosure of corporate activities. Market actors were confronted with growing societal expectations of disciplined corporate conduct under conditions of heightened levels of public scrutiny. Corporate scandals also drove the wish for restoring public trust in financial markets. The announcement of the recapitalization of the finance sector in October 2008 perpetuated skepticism in the performance of unregulated markets and halted liberalization trends. Stakeholders demanded governmental control of corporate social conduct and pushed for financial market regulations. A redefined interplay of public and private sector forces was meant to ensure social responsibility and strengthen confidence in financial markets (Deegan \& Blomquist, 2006; Kotler \& Lee, 2005). Governmental bailouts renewed public claims in financial market 
control to lower agency default risks. In his historic inauguration speech, US President Barack Obama drew attention to the importance of social responsibility for economic prosperity, voicing the collective demand for a well-balanced interplay of public and private forces: "Regained regulatory power should ensure social responsibility in the corporate and finance world as a prerequisite for sustainable markets. Legislative reforms and governmental regulations set out to institutionalize social responsibility in financial markets. Technocrats' "watchful eye over the market place" should oversee socially responsible financial conduct and ingrain long-term societal considerations in shortsighted market actors" (Obama, in speech, January 21, 2009). Newly installed financial market disclosure regulations set out to prevent financial fraud steering economic turmoil. Transparency of private sector activities and accountability of financial market operations should naturally lower principal-agent default risks. Public and private leaders as well as academics followed these trends by searching for financial social conscientiousness-enhancing market structures, while investors aimed at restoring general public trust in financial markets - e.g., the theme of the 2011 Bretton Woods Institute for New Economic Thinking conference (Nowotny, in speech, 2009; Tumpel-Gugerell, 2009).

The renewed acknowledgement of financial social conscientiousness as well as the regulatory renaissance in the finance world are believed to make SRI prosper (Duchac, 2008; Roberts, 2010). Ever since its existence, Financial Social Responsibility has been perpetuated by socially and environmentally problematic situations and flourished in the eye of socio-political deficiencies. As for being less volatile during cyclical changes and more robust for whimsical market movements during economic turmoil, socially responsible funds are proven as crisis-stable market options. Especially negative screenings are extremely robust in times of heightened uncertainty - as socially conscientious investors remain loyal to core values even during uncertainty. Given this track record of growth and stability in times of societal and economic downturns, nowadays SRI appears as a favorable market strategy. Research-based transparency campaigns could aid this trend by promoting SRI as a crisis-stable market option. Concurrent executive education may also nurture social conscientiousness in financial leaders as role models who motivate others to follow their paths.

In the aftermath of the 2008/09 financial meltdown, SRI appears as a powerful means to implement financial social conduct and thereby opens a window of opportunity for re-establishing stakeholders' trust in financial markets. Ingraining social conscientiousness in financial markets promises to positively echo in the industry and thereby bring positive socio-economic change. If the majority of investors are socially responsible and social 
conscientiousness becomes a standard feature of financial decisionmaking, this will also reflect positively on corporate social performance. If more and more investors are willing to pay for socially responsible assets, firms in general will be incentivized to adopt more socially responsible practices. In this scenario, all investors will have to accept some degree of socially responsible contributions in response to rising socially conscientious market options. SRI thus holds the potential to lift entire market industries to a more socially favorable level in the future.

While Financial Social Responsibility appears as the optimum means to avert future socially irresponsible corporate conduct and an after-crisis catharsis may have opened a window of opportunity for a prospected rise of SRI, little is actually known about the socioeconomic impact of the financial crisis on SRI in the interplay of financial markets and real economies. In the currently newly restructured economic markets that more than ever are attentive to the idea of Financial Social Responsibility of disciplined market actors, future studies may innovatively capture SRI trends during this unprecedented time of economic change.

\section{Future perspectives}

In the aftermath of the 2008/09 World Financial Crisis, the demand for ingraining ethicality in financial decision-making has reached unprecedented momentum. If SRI is not further investigated at this unique moment in time, the enormous potential of SRI as an emergent risk prevention and means to imbue trust in the post-2008/09 World Financial Crisis economy would be missed (Puaschunder, 2016a). As a window of opportunity for change, the world's most severe financial meltdown since the great depression underlined the fact that classic financial and economic theories do not accurately model the full realm of Financial Social Responsibility decision making outcomes. In newly restructuring economic markets demanding social responsibility of disciplined market actors, future studies may capture novel SRI trends. When investigating the impact of the 2008/09 World Financial Crisis on SRI, a holistic viewpoint on Financial Social Responsibility must be taken. Innovatively coupling individual decision-making research findings' with insights on external influences on social responsibility promises to help in managing financial market social responsibility risks for society. While micro-behavioral economists may in particular unravel human socially responsible cognition in the search for human-imbued ethicality nudges, macroeconomists may explain how individual social responsibility can shape collective market outcomes.

General investigations of the perception of SRI in the aftermath of the 2008/09 financial downturn could determine in what way the 
financial crisis has changed the financial community's view of economic markets' social responsibility obligations. Once-in-a-century available information on the social representations of financial social conscientiousness in post-crisis markets should be reaped as a unique source on societal perceptions of financial market reforms. Studying investors' cognition on SRI in this unique point in time also provides an innovative snapshot of the current crises' potentials to ingrain ethicality in competitive market systems.

Concurrent multi-stakeholder analyses may attribute the newly defined role of public and private constituents in social contributions and search for the optimum balance of deregulated market systems and governmental control in providing Financial Social Responsibility. Capturing real-market social responsibility phenomena could thereby not only help in finding well-tempered public-private partnership networks to support modern market economies. Oversight accountability could also present information on corporate and financial social conduct that will lead academics, technocrats, and practitioners to reflect deeper about responsibility within market systems and rethink their roles in backing socially favorable market structures.

While ingraining social conscientiousness in financial market appears as a panacea to avert future economic crisis, behavioral economists may contribute their insights on the human natural laws of social responsibility (Puaschunder, 2011). Behavioral ethics specialists may inform the role of bounded rationality for financial-social cognition and investigate accidental ethicality mishaps in financial markets in laboratory experiments (Bazerman \& Tenbrunsel, 2011; Shu, Gino \& Bazerman, 2011). Becoming aware of the bounds of human ethicality will help in reducing cognitive barriers on moral dilemmas and alleviate potential financial-social decision-making predicaments (Bazerman \& Moore, 2009).

Evolutionary psychologists may explore the emergence of ethicality in human beings by investigating which aspects of social responsibility are ingrained in human traits and the constitution of mind and which ones are nurtured by external factors. Organizational behavior scholars may add by attributing how goals can stipulate ethicality. Unpacking social responsibility incentives but also goal setting with accidental negative externalities appear as interesting research avenues. In the case of financial markets, short-term goals can lead to critically trade-off from long-term societal endeavors (Shilon, 2011; Tsay, Shu \& Bazerman, 2011). Extensions of current SRI could focus on curbing shortsightedness in financial market decisions with implicit negative societal externalities. For instance, as a fortification of political divestiture advocating for conscientiousness of financial market transactions, socially harmful, shortsighted day-trading in externally-shocked crises markets could be considered for ethical 
scrutiny. As the most recent example, divestiture from Japan in the aftermath of the 2011 nuclear crisis underlined how investment withdrawals during times of external shocks can add additional frictions to already weakened economies. In the case of Japan, it took several days until shortsighted arbitrage trades unethically pressuring the already-fragile Japanese market with additional financial unrest were stopped. Respective international financial market regulations would have been a quicker-to-hand solution to curb unintended socially harmful negative externalities caused by the collective impact of shortsighted day-traders going short on Japan. The case of Japan outlines our understanding of what a globalized world implies, remaining limited in the domain of collective social responsibility. Regulations appear to be lagging behind when considering novel challenges in the eye of interdependent economic, institutional, and political networks determining financial market moves. New risks are imposed onto corporate and financial actors by fast-paced information flows that increase the complexity of decision-making contexts and the cognitive overload of fallible financial leaders. Wading through these newly created multi-complex environments has become a formidable task for public technocrats and private practitioners. Science may attribute how a globalizing world moderates individuals' decision making on social responsibility in order to avert predictable surprises of future global crises. Future research on the fallibility of human decision-makers and external, global influences on social responsibility may help in deriving recommendations on how to steer socially conscientious behavioral patterns in modern economic markets. All these endeavors are aimed at fostering Financial Social Responsibility as a future guarantor of economic stability and sustainable social progress throughout the world. As an overarching goal, helping to leverage SRI into a more mainstream economic trend by fostering financial social conscientiousness as an implicit financial crises mitigation means can aid financial market stability. This piece will hopefully contribute to a future rise of social responsibility in our currently globalizing, economically transforming, and environmentallyfragile world, in which we should certainly feel responsible. 


\section{REFERENCES}

Ahmad, M. (2008). Global CEOs at World Economic Forum cite sovereign wealth funds as the new power broker. BI-ME, January 24, 2008.

Alperson, M., Tepper-Marlin, A. T., Schorsch, J. \& Wil, R. (1991). The better world investment guide: One hundred companies whose policies you should know about before you invest your money. From the Council on Economic Priorities. Prentice Hall: New York.

Bazerman, M. H. \& Moore, D. (2009). Judgment in managerial decision making. Hoboken: Wiley.

Bazerman, M. H. \& Tenbrunsel, A. E. (2011). Blind spots: Why we fail to do what's right and what to do about it. Princeton: Princeton University Press.

Beltratti, A. (2003). Socially responsible investment in general equilibrium: Economic theory and applications. Retrieved from the internet at www.ssrn.com.

Biller, A. (2007). Socially responsible investing now part of the landscape. Benefits \& Compensation Digest, 44, 12.

Bollen, N. P. B. \& Cohen, M. A. (2004). Mutual fund attributes and investor behavior. Unpublished working paper, Vanderbilt University.

Borok, T. (2003). A modern approach to redefining in the best interests of the corporation. Windsor Review of Legal and Social Issues, 15, 113.

Brenner, R. (2001). The force of finance: Triumph of the capital markets. New York: Texere.

Broadhurst, D., Watson, J. \& Marshall, J. (2003). Ethical and socially responsible investment. A reference guide for researchers. München: Saur.

Bruyn, S. T. (1987). The field of social investment. Cambridge, MA: Cambridge University Press.

Corfield, A. (1998). The stakeholder theory and its future in Australian corporate governance: A preliminary analysis. Bond Law Review, 10, 2, 213-232.

Cuesta de la, G. M. \& Valor, C. (2007). Fostering corporate social responsibility through public initiative: From the EU to the Spanish case. Journal of Business Ethics, 55, 3, 275-293.

Cummings, L. A. (2000). The financial performance of ethical investment trusts: An Australian perspective. Journal of Business Ethics, 25, 3, 167-177.

Deegan, C. \& Blomquist, C. (2006). Stakeholder influence on corporate reporting: An exploration of the interaction between WWF-Australia and the Australian minerals industry. Accounting, Organizations and Society, 31, 343-372. 
Dhrymes, P. J. (1998). Socially responsible investment: Is it profitable? The investment research guide to socially responsible investing. The Colloquium on Socially Responsible Investing. Retrieved from the internet at http://www.columbia.edu/ pjd1/

Duchac, J. (2008). The perfect storm: A look inside the 2008 financial crisis. Vienna University of Economics and Business talks special notes, December 15, 2008.

Dupré, D., Girerd-Potin, I. \& Kassoua, R. (2008). Adding an ethical dimension to portfolio management. Retrieved from the internet at www.ssrn.com.

Geczy, Ch. C., Stambaugh, R. F. \& Levin, D. (2003). Investing in socially responsible mutual funds. Philadelphia, PA: The Wharton School.

Guenster, N., Derwall, J., Bauer, R. \& Koedijk, K. (2005). The economic value of corporate ecoefficiency. Unpublished working paper, Erasmus University.

Harvey, C. (2008). Campbell R. Harvey's hypertextual finance glossary. Retrieved from the internet at http://www.duke.edu/ charvey/Classes/wpg/bfglosa.htm.

Jones, S., van der Laan, S., Frost, G. \& Loftus, J. (2008). The investment performance of socially responsible investment funds in Australia. Journal of Business Ethics, 80, 2, 181-203.

Knoll, M. S. (2008). Socially responsible investment and modern financial markets. Unpublished working paper, University of Pennsylvania Law School.

Kotler, Ph. \& Lee, N. (2005). Corporate social responsibility: Doing the most good for your company and your cause. New Jersey: Wiley.

Little, K. (2008). Socially responsible investing: Put your money where your values are. New York: Penguin.

Livesey, S. (2002). The discourse of the middle ground: Citizen Shell commits to sustainable development. Management Communication Quarterly, 15, 313-349.

Lynch-Fannon, I. (2007). The corporate social responsibility movement and law's empire: Is there a conflict? Northern Ireland Legal Quarterly, 58, 1, 1-22.

Marinov, B. \& Heiman, B. (1998). Company law and corporate governance renewal in transition economics: The Bulgarian dilemma. European Journal of Law and Economics, 6, 3, 231-262.

Mathieu, E. (2000). Response of UK pension funds to the SRI disclosure regulation. London: UK Social Investment Forum.

Matten, D. \& Crane, A. (2005). Corporate citizenship: Toward an extended theoretical conceptualization. Academy of Management Review, 30, 166-179.

Matten, D. \& Moon, J. (2004, July). "Implicit" and "Explicit" CSR: A conceptual framework for understanding CSR in Europe. 20th EGOS Colloquium, 1-3 July 2004, Ljubljana, Slovenia. 
McCann, L., Solomon, A. \& Solomon, J. F. (2003). Explaining the growth in U.K. socially responsible investment. Journal of General Management, 28, 4, 15-36.

McWilliams, A. \& Siegel, D. (1996). The use of event studies in management research. Academy of Management Best Papers Proceedings, 338-342.

McWilliams, A. \& Siegel, D. (2000). Corporate social responsibility and financial performance: Correlation or mis-specification? Strategic Management Journal, 21, 603-609.

Mohr, L. A. \& Webb, D. J. (2005). The effects of corporate social responsibility and price on consumer responses. Journal of Consumer Affairs, 39, 1, 121-147.

Mohr, L. A., Webb, D. J. \& Harris, K. E. (2001). Do consumers expect companies to be socially responsible? The impact of corporate social responsibility on buying behavior. Journal of Consumer Affairs, 35, 1, 45-72.

Puaschunder, J. M. (2010). On Corporate and Financial Social Responsibility. Unpublished Doctoral Thesis. University of Vienna, Faculty of Psychology.

Puaschunder, J. M. (2011). Intergenerational equity as a natural behavioral law. United States Copyright Office record TXu1-743-422. Library of Congress of the United States. Washington, D.C., USA.

Puaschunder, J. M. (2016a). Socially Responsible Investment as emergent risk prevention and means to imbue trust in the post-2008/2009 world financial crisis economy. In: O. Lehner (Ed.), Routledge Handbook of Social and Sustainable Finance, 222-238, London: Taylor \& Francis.

Puaschunder, J. M. (2016b). The role of political divestiture for sustainable development. Journal of Management and Sustainability, 6, 1, 76-91.

Reinhardt, F. L., Stavins, R. N. \& Vietor, R. H. (2008). Corporate social responsibility through an economic lense. Working paper, Harvard Kennedy School.

Renneboog, L. D. R., Horst, J. R. T. \& Zhang, C. (2007). Socially responsible investments: Methodology, risk and performance. Tilburg University Center for Economic Research Discussion Paper 2007-2031, Tilburg, The Netherlands.

Roberts, A. S. (2006). Blacked out: Government secrecy in the information age. Cambridge, MA: Cambridge University Press.

Roberts, A. S. (2010). Disciplined democracies: Global capitalism and the new architecture of government. Oxford: Oxford University Press.

Roe, M. (2000). Political preconditions to separating ownership from corporate control. Stanford Law Review, 53, 539-586.

Rosen, B. N., Sandler, D. M. \& Shani, D. (1991). Social issues and socially responsibility investment behavior: Preliminary empirical investigation. Journal of Consumer Affairs, 25, 2, 221-234. 
Schroeder, M. (2003). Socially responsible investments in Germany, Switzerland, and the United States. Centre for European Economic Research Discussion Paper 03-10, March 2003.

Schueth, S. (2003). Socially responsible investing in the United States. Journal of Business Ethics, 43, 189-194.

Shilon, N. (2011). Illusory equity holding policies. Unpublished working paper, Harvard Law School.

Shu, L. L., Gino. F. \& Bazerman, M. H. (2011). Dishonest deer, clear conscience: Self preservation through moral disengagement and motivated forgetting. Personality and Social Psychology Bulletin, 37, 4, 330-349.

Social Investment Forum Report (2006). Report on socially responsible investing trends in the United States. Social Investment Forum Industry Research Program 10-year review, January 24, 2006.

Solomon, J. F., Solomon, A. \& Norton, S. D. (2002), Socially responsible investment in the UK: Drivers and current issues. Journal of General Management, 27, 3, 1-13.

Soros, G. (2008). The new paradigm for financial markets: The credit crisis of 2008 and what it means. New York: Public Affairs.

Sparkes, R. (2002). Socially responsible investment: A global revolution. Cronwall: Wiley.

Sparkes, R. \& Cowton, Ch. J. (2004). The maturing of socially responsible investment: A review of the developing link with corporate social responsibility. Journal of Business Ethics, 52, 45-57.

Starr, M. (2008). Socially responsible investment and pro-social change. Journal of Economic Issues, $42,1,51-73$.

Steurer, R. (2010). The role of governments in corporate social responsibility: Characterising public policies on CSR in Europe. Policy Science, 43, 49-72.

Stone, B. K., Guerard, J. B., Gületkin, M. N. \& Adams, G. (2001). Socially responsible investment screening: Strong evidence of no significant cost for actively managed portfolios. Working paper. Retrieved from the internet at http://www.socialinvest.org/pdf/research/Moskowitz/2001\%20Honorable\%20Mention\%20\%20Moskowitz.pdf

Sutton, M. (2004). Between a rock and a judicial hard place: Corporate Social Responsibility reporting and potential legal liability under Kasky v. Nike. University of Missouri-Kansas City School of Law Review, 72, 1159.

Teoh, S. H., Welch, I. \& Wazzan, C. P. (1999). The effect of socially activist investment politics on the financial markets: Evidence from the South African boycott. Journal of Business, 72, 1, $35-89$. 
Tippet, J. (2001). Performance of Australia's ethical funds. Australian Economic Review, 34, 2, 170178.

Tsay, C., Shu, L. L. \& Bazerman, M. H. (2011). Naivete and cynicism in negotiations and other competitive contexts. Academy of Management Annals, in press.

Tumpel-Gugerell, G. (2009). Monetary policy challenges in the light of the current financial market development. Notes to the speech delivered at the Vienna Alpbach Talks, June 15, 2009.

Voorhes, M. (1999). The US divestment movement: How sanctions work: Lessons from South Africa. New York: St. Martin's.

Williams, G. (2005). Are socially responsible investors different from conventional investors? A comparison across six countries. Unpublished working paper, University of Bath.

Wolff, M. (2002). Response to “Confronting the critics.” New Academy Review, 1, 230-237. 